\title{
Rethinking the Role of Nitrogen and Phosphorus in the Eutrophication of Aquatic Ecosystems ${ }^{1}$
}

\author{
Ashley Smyth, H. Dail Laughinghouse IV, Karl Havens, and Thomas Frazer ${ }^{2}$
}

Historically, environmental agencies have sought to improve the water quality of freshwater lakes and rivers by managing a single nutrient. Phosphorus was the primary nutrient of concern in freshwater systems, and nitrogen was regulated in coastal/estuarine systems. Current research indicates that we must reduce both phosphorus and nitrogen to reverse eutrophication symptoms for all aquatic systems.

Nutrients are chemical elements that influence the productivity of all ecosystems. Nitrogen and phosphorus are two nutrients that are essential for the growth and survival of plants and animals but are often present in short supply in natural systems. The intentional (point source) and unintentional (non-point source) addition of nutrients into aquatic systems is an artifact of human activities and can impact the water quality of these ecosystems. This publication contains information for stakeholders, students, scientists, and environmental agencies interested in understanding how nitrogen and phosphorus affect water resources.

\section{Excess Nutrients and the Detrimental Effects of Eutrophication}

Nutrients are essential for all life, but excess nutrients can be detrimental. Both nitrogen and phosphorus are applied regularly through fertilizer to increase the yield of crops needed to feed human populations. Fertilizers are also used widely for residential and commercial landscaping purposes. Environmental concerns arise when nitrogen and phosphorus are leached into the groundwater or delivered as runoff during rainfall events to streams, rivers, lakes and estuaries. Excess nutrients in aquatic systems can stimulate growth of plants and algae. In other words, these nutrients continue to serve as fertilizers once they reach the water because they can feed the aquatic flora. Increased nutrient delivery and the consequent proliferation of plants and algae in aquatic systems is a process known as eutrophication.

Nutrient concentrations in lakes, rivers and estuaries vary widely and depend largely on the local geology and soil conditions. Low-nutrient waters with low amounts of algae are referred to as oligotrophic systems. High-nutrient waters with correspondingly high amounts of algae are referred to as eutrophic systems, while waters with intermediate levels of nutrients are known as mesotrophic systems. Increased nutrient delivery to lakes and estuaries can cause a transition from an oligotrophic state to a eutrophic state.

In extreme cases of eutrophication, microscopic algae that grow in the water column reach densities so high that they reduce the light available to rooted plants living on the bottom. This shading effect may cause the plants to

1. This document is SGEF190, one of a series of the Department of Soil and Water Sciences, UF/IFAS Extension. Original publication date April 2012. Revised January 2022. Visit the EDIS website at https://edis.ifas.ufl.edu for the currently supported version of this publication.

2. Ashley Smyth, assistant professor, Department of Soil and Water Sciences, UF/IFAS Tropical Research and Education Center; H. Dail Laughinghouse, assistant professor, Agronomy Department, UF/IFAS Fort Lauderdale REC; Karl Havens, director, Florida Sea Grant (deceased); and Thomas Frazer, professor, College of Marine Science, University of South Florida (former author); UF/IFAS Extension, Gainesville, FL 32611.

The Institute of Food and Agricultural Sciences (IFAS) is an Equal Opportunity Institution authorized to provide research, educational information and other services

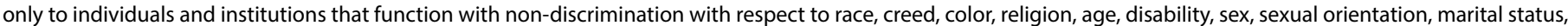

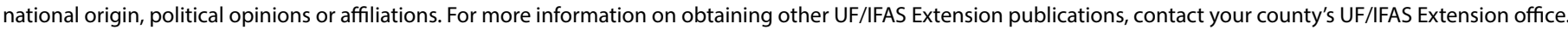
U.S. Department of Agriculture, UF/IFAS Extension Service, University of Florida, IFAS, Florida A \& M University Cooperative Extension Program, and Boards of County Commissioners Cooperating. Andra Johnson, dean for UF/IFAS Extension. 
die, resulting in the loss of important habitat for fish and other organisms. Loss of plants can, in fact, compromise the ecological and economic integrity of lakes, rivers and estuaries. Greater production of algae may also lead to an increase in the frequency and duration of periods of low dissolved-oxygen concentration known as hypoxic events, which can cause further damage to the system. Algal blooms may lead to hypoxia because as the algae die, they are decomposed by bacteria. The process of decomposition consumes oxygen from the water, resulting in areas of low oxygen and hypoxia.

Nutrient-enriched aquatic systems sometimes become dominated by noxious species of planktonic (i.e., freefloating) algae that massively proliferate, discoloring the water and sometimes forming surface scums. This phenomenon is called a "bloom." Some of these algal species (especially blue-green algae [cyanobacteria]) produce toxic compounds that can negatively impact plants and animals, including humans. Because algal blooms can have these negative consequences, these events are called "harmful algal blooms" (HABs). However, not all blooms are planktonic and occur in the water column. There are increasing reports of algal blooms on the sediments, or benthic blooms, worldwide (Wood et al. 2020). Also, inland HABs in Florida are usually dominated by cyanobacteria, while coastal HABs are dominated by dinoflagellates, diatoms, pelagophytes, haptophytes, and raphidophytes.

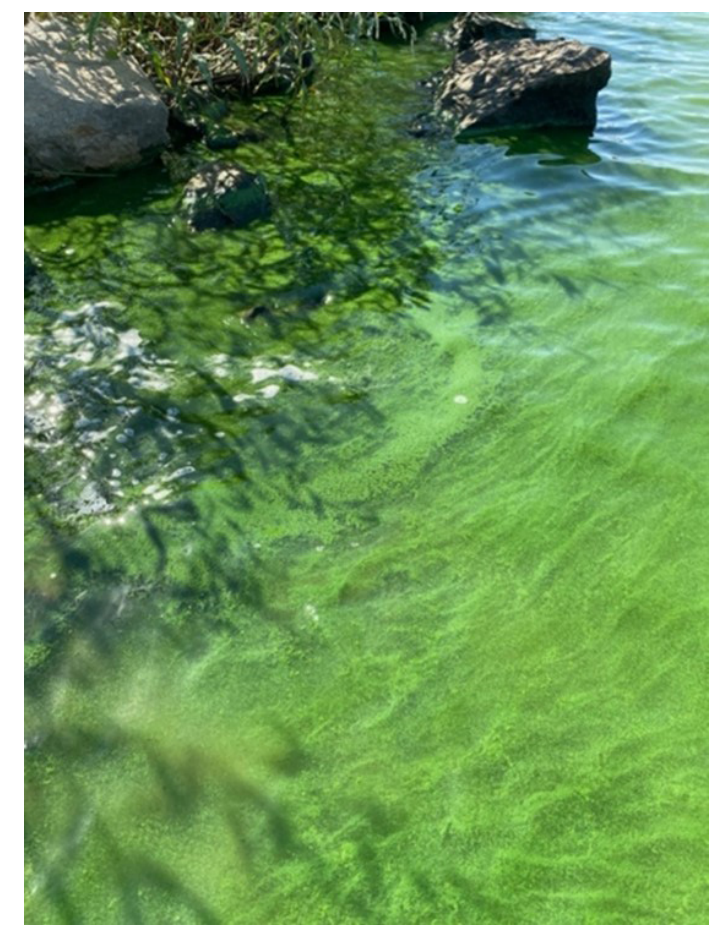

Figure 1. Aerial image of a cyanobacterial (blue-green algal) bloom in a lake.

Credits: H. Dail Laughinghouse, UF/IFAS

\section{Should one or both nutrients be controlled?}

For many years, eutrophic conditions in inland freshwater systems have been attributed more to excessive inputs of phosphorus than nitrogen. More recent evidence suggests that both nitrogen and phosphorus are important (Conley et al. 2009; Lewis et al. 2011; Paerl et al. 2016) and that improving water quality in certain lakes and estuaries that have experienced man-made eutrophication requires mitigating both nutrients.

The historical focus on phosphorus is supported by a large body of research conducted in the 1970s, mostly in Canada and other temperate regions (Schindler et al. 1971, 2008; Chow-Fraser et al. 1994). Intense algal blooms were stimulated by experimental additions of large amounts of phosphorus to nutrient-poor Canadian lakes, whereas substantial additions of nitrogen had no such effect. Researchers also focused more on the role of phosphorus because it is much less available than nitrogen to plants and animals in the freshwater environment, and thus considered a more important factor that limits growth. In fact, certain species of cyanobacteria can obtain the nitrogen they require from the atmosphere through the chemical process of nitrogen fixation, thus theoretically creating a nearly limitless nitrogen source for these aquatic ecosystems.

We now know that the research from temperate lakes may not apply to subtropical and tropical lakes or to estuaries and coastal waters. For example, subtropical lakes often have blooms of species of cyanobacteria that do not fix atmospheric nitrogen; however, nitrogen fixation can be carried out by bacteria associated with the algae (Cook et al. 2020). The growth of these algae is mainly stimulated by inputs of nitrogen from inflowing rivers, streams and land, including nutrients in fertilizer and other organic pollutants (Harris and Smith 2017). One genus that forms blooms, Microcystis, can produce potent (cyano)toxins that harm aquatic animals-and can potentially harm people if they drink or recreate in water that has a toxic bloom. These algae can start growing on lake-bottom sediments, which are rich in accumulated phosphorus. As they rise through the water column, they take up nitrogen and can attain bloom levels by the time they reach the surface. Just controlling external inputs of phosphorus may have a limited impact on Microcystis and its negative effects, depending on the ecosystem's internal reserves of phosphorus. 


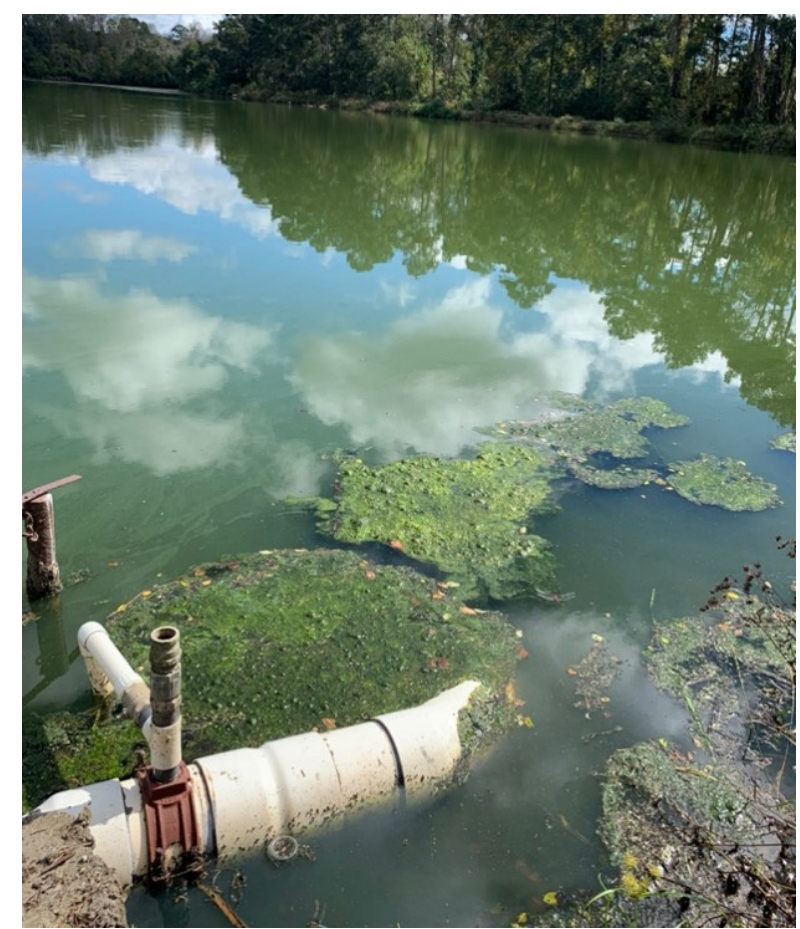

Figure 2. A cyanobacteria bloom in a lake in Havana, FL. Credits: H. Dail Laughinghouse, UF/IFAS

Primary production in coastal and estuarine systems is thought to be nitrogen limited, which means that additional inputs of nitrogen, not phosphorous, would cause eutrophication (Howarth and Marino 2006). To better understand the role of nitrogen on algal growth in coastal systems, oceanographers conducted a study similar to the work in Canadian lakes. This time they added nitrogen and phosphorus to coastal waters. Unlike the freshwater lake study, the addition of phosphorus had no effect on algal growth; rather, the nitrogen was the nutrient that had the biggest effect on algal growth (Oviatt et al. 1995). Researchers have identified several factors that cause nitrogen to be more important for algal growth and eutrophication in coastal systems than in lakes. For example, while nitrogen fixation does occur in coastal areas, there are fewer nitrogen fixers, and rates of nitrogen fixation are low. Further, coastal areas not only receive nutrient inputs from the land but also from the ocean. Nutrient inputs from the ocean can be large, particularly for phosphorous, because phosphorous is highly abundant in the ocean compared to nitrogen.

The ocean is often limited by nitrogen rather than phosphorus because there are natural processes that occur there that permanently remove nitrogen, but there are no corresponding processes that permanently remove phosphorus. For example, denitrification is a natural process performed by microbes that occurs primarily in sediments converting inorganic nitrogen into nitrogen gas, permanently removing nitrogen from the aquatic ecosystem. The ocean's salinity also helps to contribute to nitrogen limitation. Salinity causes the release of phosphorus that would otherwise be stored in sediments, making more phosphorous available in the water, and leading to nitrogen being the limiting nutrient. Thus, algae in coastal systems respond primarily to nitrogen delivered by terrestrial runoff from human activities, such as fertilizer application and sewage. In excess, these inputs often stimulate algal blooms, though these blooms are different species than those that bloom in freshwater systems.

While there are some cases in temperate lakes where controlling phosphorus alone reversed the symptoms of eutrophication, there also are cases where the reduction of phosphorus upstream left high levels of nitrogen in the water, unused by the algae in the lake. When transported downstream, this nitrogen caused harmful blooms of algae in estuaries. In essence, the problem was transferred from the inland aquatic ecosystem to the coastal zone. Therefore, controlling both nitrogen and phosphorous inputs can help control toxic algal blooms in some inland waters and reduce nitrogen export to downstream ecosystems that are sensitive to excess nitrogen.

Traditionally, efforts to control eutrophication have focused on managing either $\mathrm{N}$ or $\mathrm{P}$. Yet, in many cases, primary production is co-limited by both nutrients (Paerl et al. 2016). For many lakes, regulatory agencies had suggested $P$ reduction programs to prevent eutrophication, but even after reductions, water quality goals were not achieved (Conley et al. 2009). When regulators managed $\mathrm{P}$ inputs but not $\mathrm{N}$, the proportion of $\mathrm{N}$ increased relative to $\mathrm{P}$. Changes to the ratio can affect the composition of the algal community, even shifting to toxin-producing species (Gobler et al. 2016). There are also ecosystem consequences of changing the nutrient ratios. Growth of different species can affect light, oxygen, and $\mathrm{pH}$, which impact transformations in the sediments and water column (Glibert et al. 2011). Single-nutrient removal strategies change the proportion of nutrients, which can shift environmental conditions. Thus, single-nutrient reduction strategies may have unintended consequences for aquatic ecosystems.

The current body of science suggests it is prudent to implement nutrient-control strategies that limit both nitrogen and phosphorus to effectively manage eutrophication of lakes and estuaries. This approach must be weighed carefully considering both the costs and benefits because control of nitrogen may be considerably more costly than control of phosphorus alone. 


\section{References}

Chow-Fraser, P., D. O. Trew, D. Findlay, and M. Stainton. 1994. "A Test of Hypotheses to Explain the Sigmoidal Relationship between Total Phosphorus and Chlorophyll a Concentrations in Canadian Lakes." Canadian Journal of Fisheries and Aquatic Sciences 51 (9): 2052-2065. https:// doi.org/10.1139/f94-208

Conley, D. J., H. W. Paerl, R. W. Howarth, D. F. Boesch, S. P. Seitzinger, K. E. Havens, C. Lancelot, and G. E. Likens. 2009. "Controlling Eutrophication: Nitrogen and Phosphorus." Science 323 (5917): 1014-1015. https://doi. org/10.1126/science. 1167755

Cook, K. V., C. Li, H. Cai, L. R. Krumholz, K. D. Hambright, H. W. Paerl, M. M. Steffen, A. E. Wilson, M. A. Burford, H. Grossart, D. P. Hamilton, H. Jiang, A. Sukenik, D. Latour, E. I. Meyer, J. Padisák, B. Qin, R. M. Zamor, and G. Zhu. 2020. "The Global Microcystis Interactome." Limnology and Oceanography 65 (S1): S194-S207. https:// doi.org/10.1002/lno.11361

Glibert, P. M., D. Fullerton, J. M. Burkholder, J. C. Cornwell, and T. M. Kana. 2011. "Ecological Stoichiometry, Biogeochemical Cycling, Invasive Species, and Aquatic Food Webs: San Francisco Estuary and Comparative Systems." Reviews in Fisheries Science 19 (4): 358-417. https://doi.org/ 10.1080/10641262.2011.611916

Gobler, C. J., J. M. Burkholder, T. W. Davis, M. J. Harke, T. Johengen, C. A. Stow, and D. B. V. de Waal. 2016. "The Dual Role of Nitrogen Supply in Controlling the Growth and Toxicity of Cyanobacterial Blooms." Harmful Algae 54:87-97. https://doi.org/10.1016/j.hal.2016.01.010

Harris, T. D., and V. H. Smith. 2017. "Do Persistent Organic Pollutants Stimulate Cyanobacterial Blooms?" Inland Waters 6 (2): 124-130. https://doi.org/10.5268/IW-6.2.887

Howarth, R. W., and R. Marino. 2006. "Nitrogen as the Limiting Nutrient for Eutrophication in Coastal Marine Ecosystems: Evolving Views over Three Decades." Limnology and Oceanography 51 (1.2): 364-376. https://doi. org/10.4319/lo.2006.51.1_part_2.0364

Lewis, W. M., W. A. Wurtsbaugh, and H. W. Paerl. 2011. "Rationale for Control of Anthropogenic Nitrogen and Phosphorus to Reduce Eutrophication of Inland Waters." Environmental Science \& Technology 45 (24): 10300-10305. https://doi.org/10.1021/es202401p
Oviatt, C., P. Doering, B. Nowicki, L. Reed, J. Cole, and J. Frithsen. 1995. "An Ecosystem Level Experiment on Nutrient Limitation in Temperate Coastal Marine Environments." Marine Ecology Progress Series 116:171-179. https:// doi.org/10.3354/meps116171

Paerl, H. W., J. T. Scott, M. J. McCarthy, S. E. Newell, W. S. Gardner, K. E. Havens, D. K. Hoffman, S. W. Wilhelm, and W. A. Wurtsbaugh. 2016. "It Takes Two to Tango: When and Where Dual Nutrient (N \& P) Reductions Are Needed to Protect Lakes and Downstream Ecosystems." Environmental Science \& Technology 50 (20): 10805-10813. https:// doi.org/10.1021/acs.est.6b02575

Schindler, D. W., F. A. J. Armstrong, S. K. Holmgren, and G. J. Brunskill. 1971. "Eutrophication of Lake 227, Experimental Lakes Area, Northwestern Ontario, by Addition of Phosphate and Nitrate." Journal of the Fisheries Board of Canada 28 (11): 1763-1782. https://doi.org/10.1139/ f71-261

Schindler, D. W., R. E. Hecky, and D. L. Findlay. 2008. "Eutrophication of Lakes Cannot Be Controlled by Reducing Nitrogen Input: Results of a 37-Year Whole-Ecosystem Experiment." Proceedings of the National Academy of Sciences 105 (32): 11254-11258. https://doi.org/10.1073/ pnas. 0805108105

Wood, S. A., L. T. Kelly, K. Bouma-Gregson, J. Humbert, H. D. Laughinghouse, J. Lazorchak, T. G. McAllister, A. McQueen, K. Pokrzywinski, J. Puddick, C. Quiblier, L. A. Reitz, K. G. Ryan, Y. Vadeboncoeur, A. Zastepa, and T. W. Davis. 2020. "Toxic Benthic Freshwater Cyanobacterial Proliferations: Challenges and Solutions for Enhancing Knowledge and Improving Monitoring and Mitigation. Freshwater Biology 65 (10): 1824-1842. https://doi. org/10.1111/fwb.13532

\section{Recommended Reading}

Howarth, R., D. Anderson, J. Cloem, C. Elfring, C. Hopkinson, B. Lapointe, T. Malone, N. Marcus, K. McGlathery, A. Sharpley, and D. Walker. Nutrient Pollution of Coastal Rivers, Bays, and Seas. 2000. Vol. 7 of Issues in Ecology. Washington, D.C.: Ecological Society of America. Retrieved from https://www.esa.org/wp-content/uploads/2013/03/ issue7.pdf 


\section{Acknowledgments}

The authors are grateful to Professors Mark Brenner (UF

Geology Department) and Edward Phlips (UF/IFAS School

of Forest Resources and Conservation) for substantive and constructive comments and to Dorothy Zimmerman

(Florida Sea Grant) for editorial work that greatly improved the clarity of the message presented in an early version of this document. 